\title{
How is using of the Indonesian Banking Environmental Disclosure with GRI?
}

Rizky Windar Amelia ${ }^{1}$, Aditya Pandu Wicaksana², Desi Zulvina ${ }^{3}$, Sysca Lady Sulistyowatie ${ }^{4}$

1 Widya Dharma University, Klaten, Indonesia

2 Islamic University of Indonesia, Yogyakarta, Indonesia

3 Sebelas March University, Surakarta, Indonesia

4 Widya Dharma University, Klaten, Indonesia

\section{Article Information Abstract}

Article history:

Accepted: April 2021

Approved: Juli 2021

Published: September 2021

Keywords:

environmental disclosure,

GRI index,

ISR index,

Indonesian banking
This study aims to determine how the differences in environmental disclosure in conventional banking with Islamic banking using the GRI index. This study found that conventional banking has a higher environmental disclosure than Islamic banking. In addition, the results of this study state that the disclosure of the Islamic banking environment is more representative when using the ISR index when compared to the GRI index. The data used are in the form of annual reports and sustainability reporting of conventional banking companies and Islamic banking listed on the Indonesia Stock Exchange in 2019. The data analysis technique used in this study is content analysis and statistical tests to confirm the results.

How to Cite: Amelia, R., Wicaksana, A., Zulvina, D., \& Sulistyowatie, S. (2021). How is using of the Indonesian Banking Environmental Disclosure with GRI?. Jurnal Penelitian Ekonomi dan Bisnis, 6(2). doi:https://doi.org/10.33633/jpeb.v6i2.4355

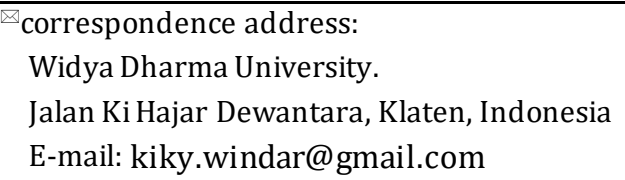




\section{INTRODUCTION}

Corporate Social Responsibility is a topic that is quite interesting to discuss in the business world as this concept is considered the core of business ethics (Nobanee \& Ellili, 2016), which can answer the demands of the community related to company activities that are deemed to meet the demands of stakeholders (Meng et al., 2020). Corporate Social Responsibility is not only based on the responsibility that rests on a single bottom line, namely the value of the company which is reflected in its financial condition. (Hummel et al., 2020). However, corporate responsibility also rests on the triple bottom lines (Sobhani et al., 2012) that, in addition to achieving financial targets, also seeks to contribute to social and environmental issues so that it will gain legitimacy for its existence in the midst of society (Ageron et al., 2012; Hart et al., 2003; Wheeler et al., 2003). Likewise, with the banking world, Corporate Social Responsibility had become an interesting new trend, especially when the United Nations (UN) launched a guide that forces the banking industry to contribute to sustainable development. (Vernon, 2015; Zhang et al., 2017). Therefore, there is a synchronization between the demands on banking performance and the concept of CSR (Nizam et al., 2019).

In Government Regulation no. 47 of 2012, apart from requiring companies to carry out social and environmental responsibility, it also states that "The implementation of social and environmental responsibility is included in the Company's annual report and is accountable to the GMS". The Indonesian government, through the Financial Services Authority (OJK) has also issued a regulation that requires financial service institutions to carry out a Corporate Social Responsibility program in the form of a sustainable report. In the Financial Services Authority Regulation No. 51 / POJK / .03 / 2017, 0JK requires all financial service institutions to prepare a sustainable financial action plan, to carry it out, and to report the sustainable finance in a sustainability report that is prepared separately from an annual report or as an inseparable part of the annual report.

Law No. 32 of 2009 on Environmental Protection and Management has also required all economic activities to comply with promoting environmental sustainability. In banking companies, it is necessary to better understand and master environmental risk management. One of these efforts can be made by encouraging banks to increase their environmentally friendly financing portfolios such as renewable energy, energy efficiency, organic agriculture, ecotourism, environmentally friendly transportation, and various eco-label products (Ziolo et al., 2019). Even though the world of banking does not have a direct relationship with environmental management, the application of the principle of responsibility in the aspects of Good Corporate Governance (GCG), it encourages banks to create added value for their products by increasing their social role in the environment (www.bi.go.id).

The company's demands to carry out specific responsibilities for the implementation of the living environment is getting higher (Baboukardos, 2018; Miah et al., 2020). In this implementation, the company shows concern and responsibility for the environment, one of which is through environmental disclosure (Ane, 2012; Tsalis et al., 2020). Environmental disclosure is a collection of information related to environmental management activities carried out by a company which can be obtained from qualitative statements, assertions, or quantitative facts, in financial reports or footnotes (Al-Tuwaijri et al., 2005; Berthelot \& Robert, 2011; Plumlee et al., 2015).

Environmental disclosure by the company is considered as one part of the communication tool between the company and its stakeholder (Belkaoui, 1980; Wang et al., 2020). Environmental disclosure reporting in Indonesia is mandatory (mandatory report), but the content disclosed is still voluntary (voluntary disclosure) (Law No. 40 of 2007 article 66 paragraph (2)). The standard guidelines for disclosure of social and environmental responsibility that are widely followed by companies in the world are the guidelines for sustainability reporting issued by the Global Reporting Initiative / GRI (Economics, 2016; Kumar et al., 2018; Tsalis et al., 2020). This study also chose to use the GRI guidelines to assess the differences in environmental disclosure between conventional banking and Islamic banking since the government in Indonesia has not yet made guidelines that can be used as the standard in reporting their social responsibility.

Banks, as financial sector institutions, are also pressured to behave ethically to run an environmentally friendly business (Dong et al., 2020). One form of ethical behavior carried out by an organization is not only to focus on achieving profit but also to pay attention to the environmental aspects (planet) and society (people) so that they are able to maintain sustainability in the long term (Dong et al., 2020; Sahoo \& Nayak, 2007). Activities of banks and financial institutions related to funding and investment policies also have a sensitive impact on the environment compared to the direct impact of companies that cause industrial pollution (Branco \& Rodrigues, 2006). 
Green banking concept (Bai et al., 2013) where a bank whose operations are environmentally friendly, has environmental responsibility and performance and considers environmental protection aspects in running its business (Sahoo \& Nayak, 2007). By considering environmental aspects in making business decisions, it can reduce the negative impact of the operating activities of financial institutions so that it can help corporate social responsibility efforts and achieve sustainability (Shaumya \& Arulrajah, 2017). Therefore, through the initiation of green banking, the bank will introduce the concept of paperless and information technology-based banking services to existing and prospective customers and, on the other hand, seek to promote the role of the bank to become responsible corporate citizens for achieving sustainable development (Fernando \& Fernando, 2017). The company's challenge in maintaining the company's image in society is the reason why a bank in Indonesia conducts social reporting (www.worldbank.org).

The concept of CSR (Corporate Social Responsibility) is developing in a conventional economy and developing in an Islamic economy. The idea of CSR in Islam is closely related to companies that carry out business activities according to the Islamic concept expected by companies that can carry out Islamic corporate social responsibility. In disclosing sustainability reports, conventional banking is higher when compared to Islamic banking (Nobanee \& Ellili, 2016). This is likewise confirmed by (Hartanti, D. dan Fitria, 2010)) who have conducted research on the comparison of conventional banking Corporate Social Responsibility (CSR) disclosures and show that traditional banking disclosures are better than Islamic banks, as seen from the GRI index and ISR index. The absence of regulations on CSR standards in sharia (Islam) causes various activities and reporting of CSR in Islamic banking to be uneven. Measurement of social performance in many Islamic banks in Indonesia still refers to the GRI Index (Saridona \& Cahyandito, 2015).

In environmental disclosure practice, Islamic banking should have a higher level. This is because Islamic banking adheres to the concept that Islamic banking has a relationship with God, humans, and the environment (Elasrag, 2015). Sharia entities are required to contribute to economic development as part of their relationship with humans and the environment in accordance with the Maqasid Sharia (Mohamed Zain et al., 2014). Moreover, in the concept of sharia which states that he is a Khalifah/leader (Mara \& Mara, 2014), humans, in this case, the company, have the responsibility to maintain all of Allah's creation (Tafti et al., 2012). The concept of CSR in Islam emphasizes that humans are Khalifah who are obliged to protect all of Allah's creation within the scope of the company (Mohamed Zain et al., 2014). There are very few studies that have compared the environmental disclosure of conventional banking with Islamic banking.

Meanwhile, related to the need for disclosure of social responsibility in Islamic banking, currently discussing the Islamic Social Reporting Index (hereinafter referred to as the ISR index)(Hartanti, D. dan Fitria, 2010). The ISR index is believed to be a starting point in terms of CSR disclosure standards in accordance with an Islamic perspective (Nugraheni \& Azlan Anuar, 2014). With the use of Islamic banking, this study also looks at the breadth of the disclosure of the Islamic banking environment as measured by the GRI-G4 indicator when compared with the use of the ISR index.

\section{METHOD}

This research belongs to qualitative research using a descriptive approach. This study focuses on analyzing information in the theoretical literature related to research topics. The data used in this research is secondary data. Secondary data is the data that already exists and does not need to be collected by researchers alone (Martins et al., 2018) or the data obtained by accessing secondary data sources that can be trusted and can be scientifically justified. The data used are in the form of annual reports and sustainability reporting for conventional and Islamic banking companies listed on the Indonesia Stock Exchange in 2019.

The data analysis technique used in this study was carried out in two stages. First, looking and understanding the differences of environmental disclosures carried out by conventional banking and Islamic banking by comparing the results of the calculation of the GRI G4 index, which consists of 34 items with content analysis. It is 0 value if there is no disclosure regarding the item and one value if there is disclosure related to the item. Furthermore, to strengthen the results in testing, the t-test statistical testing was carried out with the SPSS version 20 testing tool.

Generally speaking, the disclosure indicators in the environmental scope in GRI show the environmental dimensions of sustainability that affect the organization's impact on living and non living natural systems, including ecosystems, soil, water, and air. Meanwhile, the information disclosed in the environmental theme includes conservation environment, non-polluting the environment, 
education about the environment, awards in the environmental field, and environmental management systems (Haniffa \& Hudaib, 2007; Othman et al., 2009)

\section{RESULT AND DISCUSSION}

Descriptive statistics

\section{Environmental Disclosure GRI Index Conventional Banking vs. Islamic Banking}

The results of environmental disclosure assessment in conventional banking companies and Islamic banking are shown in the following table:

Table 1. Frequency of Disclosure of Each Item Environmental Disclosure GRI Index

\begin{tabular}{|c|c|c|c|}
\hline Code & Information & $\begin{array}{l}\text { ED Index } \\
\text { Conventional } \\
\text { Banking }\end{array}$ & $\begin{array}{l}\text { ED Index } \\
\text { Syariah } \\
\text { banking }\end{array}$ \\
\hline EN 1 & The materials used are based on weight or volume & 3.09 & 0.64 \\
\hline EN 2 & $\begin{array}{c}\text { Percentage of materials used that are recycled input } \\
\text { materials }\end{array}$ & 3.18 & 0.55 \\
\hline EN 3 & Energy consumption in the organization & 3.09 & 0.91 \\
\hline EN 4 & Energy consumption outside the organization & 2.91 & 0.91 \\
\hline EN 5 & Energy intensity & 3.18 & 0.91 \\
\hline EN 6 & Reduction in energy consumption & 3.36 & 0.91 \\
\hline EN 7 & $\begin{array}{c}\text { Reduction of energy requirements for products and } \\
\text { services }\end{array}$ & 2.82 & 0.64 \\
\hline EN 8 & Total water withdrawal by source & 2.82 & 0.82 \\
\hline EN 9 & $\begin{array}{c}\text { Water sources that are significantly affected by water } \\
\text { withdrawal }\end{array}$ & 2.91 & 0.73 \\
\hline EN 10 & $\begin{array}{c}\text { Percentage and total volume of water recycled and } \\
\text { reused }\end{array}$ & 2.18 & 0.55 \\
\hline EN 11 & $\begin{array}{l}\text { Operational locations that are owned, leased, managed } \\
\text { within, or adjacent to, protected areas and areas with } \\
\text { high biodiversity value outside protected areas }\end{array}$ & 1.00 & 0.18 \\
\hline EN 12 & $\begin{array}{c}\text { Description of the significant impact of activities, } \\
\text { products, and services on biodiversity in protected } \\
\text { areas and areas with high biodiversity value outside } \\
\text { protected areas }\end{array}$ & 1.00 & 0.18 \\
\hline EN 13 & Protected and restored habitat & 0.64 & 0.09 \\
\hline EN 14 & $\begin{array}{c}\text { Total number of species on the IUCN Red List and } \\
\text { species on the national protected species list with } \\
\text { habitats in areas affected by operations, by the level of } \\
\text { risk of extinction }\end{array}$ & 0.55 & 0.09 \\
\hline EN 15 & Direct greenhouse gas emissions & 1.18 & 0.18 \\
\hline EN 16 & Indirect greenhouse gas emissions & 1.18 & 0.18 \\
\hline EN 17 & Other indirect greenhouse gas emissions & 1.18 & 0.18 \\
\hline EN 18 & Greenhouse gas emission intensity & 1.18 & 0.18 \\
\hline EN 19 & Reduction of greenhouse gas emissions & 1.36 & 0.27 \\
\hline EN 20 & Emissions of ozone depleting substances & 0.55 & 0.27 \\
\hline EN 21 & NOX, SOX and other significant air emissions & 0.55 & 0.18 \\
\hline EN 22 & Total water discharge by quality and purpose & 2.00 & 0.45 \\
\hline EN 23 & Total waste weight by type and disposal method & 2.18 & 0.45 \\
\hline EN 24 & The number and total volume of significant spills & 2.00 & 0.45 \\
\hline EN 25 & $\begin{array}{l}\text { Weight of waste considered hazardous transported, } \\
\text { imported, exported, or treated, and percentage of waste } \\
\text { transported for international shipment }\end{array}$ & 1.09 & 0.09 \\
\hline EN 26 & $\begin{array}{l}\text { Identity, size, protected status, and biodiversity value of } \\
\text { water bodies and associated habitats significantly } \\
\text { affected by wastewater and runoff and organization }\end{array}$ & 1.00 & 0.09 \\
\hline
\end{tabular}


EN 27 The level of impact mitigation on the environmental impact of products and services

Percentage of products sold and their packaging that was reclaimed by category

The significant monetary value of fines and the total

EN 29 number of non-monetary sanctions for non-compliance with environmental laws and regulations Significant environmental impacts of transporting

EN 30 products and other goods and materials for the

organization's operations and transporting workers
Total environmental protection expenditure and investment by type

Percentage of new suppliers that were screened using environmental criteria

Significant actual and potential negative environmental impacts in the supply chain and actions taken grievance mechanism

0.18

Figure 1. The following presents a descriptive analysis of the assessments that have been obtained from the environmental disclosure of conventional banking and Islamic banking.

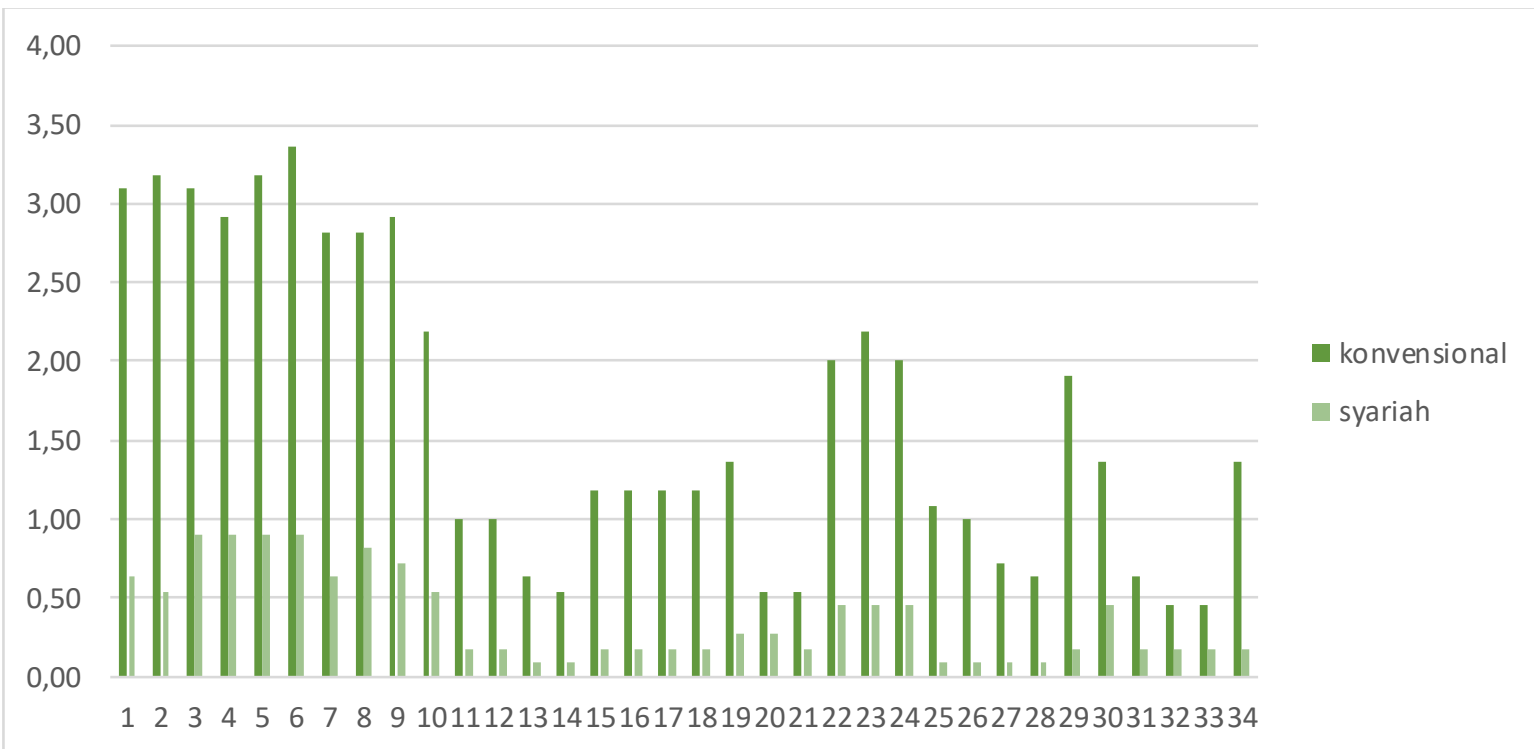

Figure 1. Comparison of Environmental Disclosure on Conventional Banking and Islamic Banking

The chart results on the environmental disclosure of conventional banking and Islamic banking (Figure 1) show that conventional banking discloses environmental items higher than Islamic banking in its annual report and sustainability reporting. This result is also confirmed in the following t-test:

Table 2. T-test results

\begin{tabular}{lrll}
\hline & Mean & $\mathrm{t}$ & $p$-value \\
& & & \\
\hline $\begin{array}{l}\text { ed_konv } \\
\text { ed_syar }\end{array}$ & 1,6388 & 10,153 &, 000 \\
\hline
\end{tabular}

From the results of the t-test that has been conducted, it shows that there are differences in environmental disclosure carried out by conventional banking with Islamic banking, and conventional 
banking is higher in disclosing environmental disclosure ( $p$-value $=0,000$, and the mean environmental disclosure of traditional banking is higher than Syariah banking). These results support the research(Nobanee \& Ellili, 2016).

\section{Environmental Disclosure Islamic banking with the GRI index vs. the ISR index}

The results of the assessment of the disclosure of the Islamic banking environment using the ISR index are as follows:

Table 3. Frequency of Disclosure of Each Environmental Disclosure Item ISR Index

\begin{tabular}{ccc}
\hline Code & Information & ED ISR Index \\
\hline ISR1 & Environmental conservation & 0.82 \\
ISR2 & Activities to reduce the effects of global warming (pollution, & 0.91 \\
& water treatment, etc.) & \\
ISR3 & Environmental education & 0.27 \\
ISR4 & Environmental awards / certifications & 0.36 \\
ISR5 & Environmental management system & 0.82 \\
\hline
\end{tabular}

To find out the difference in the average value in the environmental disclosure GRI index and the environmental disclosure ISR index, an Independent Samples Test was conducted as follows:

Table 4. Average Testing Results

\begin{tabular}{ccc}
\hline & Group & Mean \\
\hline ED & Islamic ED &, 3709 \\
& ISR &, 6360 \\
\hline
\end{tabular}

Based on the output table above, it is known that the number of environmental disclosure items for the GRI index is 34 items, while for the ISR index, there are five items. The average value of the results of environmental disclosure assessment of the mean for the GRI index is 0.3709, while for the ISR index is 0.6360 . Thus, statistically descriptive, it can be concluded that there is a difference in the average index of environmental disclosure between GRI and ISR. Furthermore, to prove whether the difference is significant (real) or not, the "Independent Samples Test" output is interpreted as follows:

Table 5. Independent Samples test results

Levene's Test for
Equality of Variances $\quad$ t-test for Equality of Means

\begin{tabular}{rcrrrr} 
& & F & Sig. & Sig. (2-tailed) & Mean Difference \\
\hline ED & Equal variances assumed & \multirow{2}{*}{031} &, 860 &, 060 &,- 26512 \\
& Equal variances not assumed & & &, 118 &,- 26512 \\
\hline
\end{tabular}

Based on the output of the "Independent Samples Test" the sig value is known. Levene's Test for Equality of Variances is $0.860>0.05$, which means that the data variance between the GRI index and the ISR index is homogeneous or the same. In the "Equal variances assumed," the sig value is known. (2-tailed) of $0.060<0.1$, so it can be concluded that there is a significance (real) between the average assessment of Islamic banking environmental disclosure and the GRI index and the ISR index.

Table 6. Homogeneity Test Results

\begin{tabular}{|c|c|c|c|}
\hline Levene Statistics & df1 & df2 & Sig. \\
\hline 12,728 & 8 & 26 & 000 \\
\hline
\end{tabular}

The obtained Levene Statistic number is 12,728 with a probability value (sig.) of 0,000 , so it can be concluded that the variants of the index used in viewing the environmental disclosure of Islamic banking are different or heterogeneous. Each disclosure theme has a sub-theme as an indicator for the disclosure of that theme (Leipziger, 2015; Traxler et al., 2018). This result is also corroborated by the plots shown as follows: 


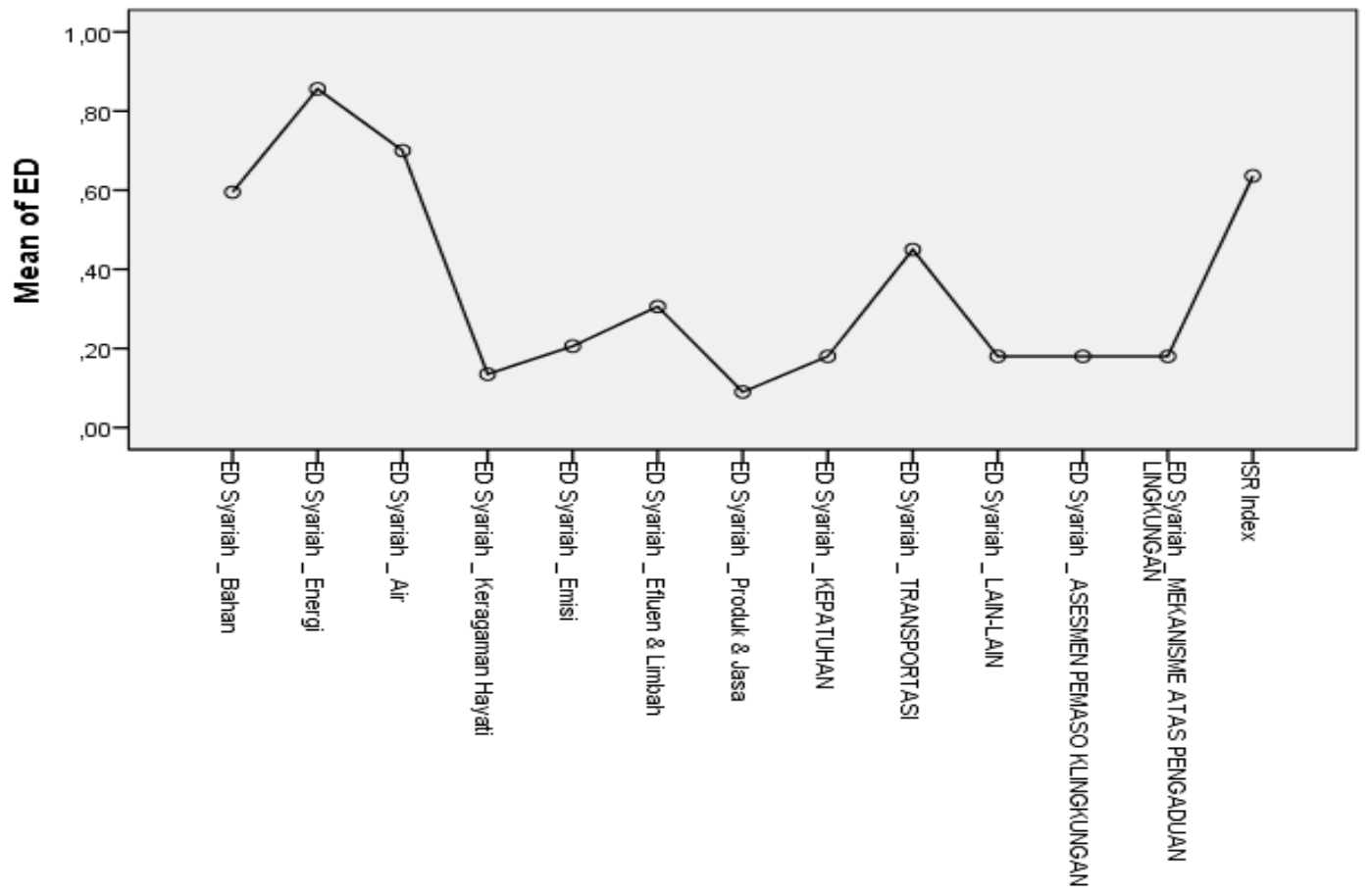

Figure 2. Plots of Aspects in the ED GRI Index and the ED ISR Index

From the results of the independent samples test, homogeneity, and plot, it can be concluded that the assessment of environmental disclosure of Islamic banking is better if using the ISR index (Belal et al., 2015; Santoso et al., 2018).

The item of reducing energy consumption is the most frequently disclosed item by conventional banking and Islamic banking. Banking in Indonesia has supported government programs as stipulated in Presidential Instruction No. 10/2005 regarding Energy Saving (Indonesian Government, 2014). In accordance with the instructions of the Financial Services Authority (0JK), companies that are in the financial sector can carry out energy conservation by going through the following stages:

Table 7. Energy Conservation Stages

\begin{tabular}{l|l}
\hline Stages & \multicolumn{1}{c}{ Effort } \\
\hline First & Prevention; eliminates waste of energy \\
Second & Recovery; reduce energy losses \\
Third & Efficiency innovation; improve the energy utilization efficiency \\
\hline
\end{tabular}

Source: Otoritas Jasa Keuangan, (2015)

The involvement of the private sector in managing environmental and social risks is also regulated in Law Number 32 of 2009 concerning Environmental Protection and Management, which, among other things, regulates the obligation for industry to protect nature and the environment. The initiation of banks to adopt green banking practices in Indonesia is inseparable from the issuance of relevant regulations that encourage the implementation of environmentally friendly banks. Various ways can be performed in the adoption of green banking, such as online banking, internet banking, green checking accounts, green loans, mobile banking, electronic banking outlets, and saving energy use that contributes to environmental sustainability programs (Gupta, 2015). (Iqbal et al., 2016) with the factor analysis approach, found one of the factors of why banks adopt green banking practices to ensure sustainable economic development, namely environmental interests. The adoption of green banking in the banking business is a crucial issue as it becomes an identifier for companies that care about the environment in their business and can strengthen their competitive advantage (Bryson et al., 2016). 
In the environmental aspect, the implementation of the Islamic banking CSR report shows that the items in the ISR index are more appropriate to measure environmental performance (Zafar \& Sulaiman, 2019). These aspects include environmental conservation, protection of endangered animals or habitats, prevention of environmental pollution, environmental education, concern for green world issues, environmental audits, and the establishment of an environmental management system.

The advantage of using the ISR index in Islamic banking disclosure compared to the GRI index is that the ISR index can reveal indicators related to transactions that occur in companies that are free from elements of usury ( riba' $^{\prime}$ ), speculation and gharar and disclosed zakat, Islamic compliance status, and social aspects. Such as alms, waqf, qard al hassan, to the disclosure of worshipping within the company environment (Sunarsih \& Ferdiansyah, 2016). The ISR index is also able to describe ethical aspects that represent accountability to God and humans as well as transparency regarding all company activities, which are needed by humans to ensure that all comply with the provisions of Allah SWT (Haniffa \& Hudaib, 2007).

\section{Stakeholder Theory}

Stakeholders are a group that is able to provide support for the existence of an organization (Parmar et al., 2010). According to (R. E. E. Freeman \& McVea, 2005) Stakeholders are groups or individuals who can influence or be influenced by the process of achieving the goals of an organization. Stakeholder theory says that a company is not an entity that only operates for its own interests but must provide benefits for its stakeholders (shareholders, creditors, consumers, suppliers, government, society, analysts, and other parties)(Laplume et al., 2008). The existence of a company is strongly influenced by the support provided by stakeholders for the company (Friedman \& Miles, 2002). (Gray et al., 1995) said that the company's survival depends on stakeholder support and that support must be sought so that the company's activity is to seek that support. The more powerful the stakeholders, the greater the company's efforts to adapt (Ullmann, 1985).

Stakeholder theory, related to the concept of corporate social responsibility, is not only limited to maximizing profit and shareholder interests but also must pay attention to the community, customers, and suppliers as part of the company's operations itself. (Argandoña, 1998). Stakeholders will support the company's operational activities if they disclose reliable and relevant information so that stakeholders continue to trust and help the company in making decisions (R. E. Freeman et al., 2017).

\section{Environmental Disclosure with the Global Reporting Initiative}

According to (Gray \& Bebbington, 2000), disclosure of corporate social and environmental responsibility aims to show the public the activities carried out by the company and the impact on society. (Clarkson et al., 2008) have a view of the environmental disclosure theory, which states that companies that have performed their environmental performance well will prefer to disclose their environmental information, which is not easily imitated by other companies with poor environmental performance. Furthermore, environmental disclosure is a collection of information related to environmental management activities by companies in the past, present, and future (Khalil \& O'sullivan, 2017).

The guidelines used to prepare a sustainability report are made by the Global Reporting Initiative (GRI), which is headquartered in the Netherlands. GRI is a non-profit organization that has pioneered guidelines for sustainability reports or reports on social and environmental responsibility (GRI, 2013). In the GRI G4 standard, performance indicators are divided into three main components, namely economic, environmental and social. The total indicators contained in the GRI reached 91 items (www.globalreporting.org). This study, using the assessment guide to compare the environmental disclosure of banking with GRI, which has become a reference for sustainable reporting guidelines around the world, to determine the differences in environmental disclosures between conventional banking and Islamic banking. In addition, GRI is considered as a tool that can harmonize many approaches related to sustainability reporting by companies (Lozano 2006b; Newport, Chesnes, and Lindner 2003).

\section{Islamic Social Reporting Index}

Islamic Social Reporting Index is an alternative to the standard of Corporate Social Responsibility disclosure for Islamic-based companies issued by the Accounting and Auditing Organization for Islamic Financial Institutions (AAOIFI). (Othman et al., 2009), developed a relevant 
disclosure index on Islamic Social Reporting (ISR). Islamic Social Reporting (ISR) is a conceptual framework for CSR disclosure based on Islamic principles that not only help make decisions for Muslims but also helps companies fulfill their obligations to Allah and society at large (Sunarsih \& Ferdiansyah, 2016). Furthermore, the conceptual framework is in accordance with the Islamic entity to reveal matters related to Islamic principles as a transaction that is free from elements of usury (riba), speculation and gharar (the sale of what is not yet present) and zakat disclosure, islamic status and social compliance aspects such as alms (sadaqah), waqf, qard al hasan (an interest-free loan), to the disclosure of worshipping in the corporate environment.

An important factor that forms the basis of sharia in the formation of Islamic Social Reporting (ISR) is Tauhid (One True God) which forms the perception of a Muslim to be willing to accept all the provisions of Islam-based on two main sources, namely Al-qur'an and Al-Hadith. All the advantages contained in the GRI Index still have disadvantages, in the sense that it is not suitable for companies that are unique, such as Islamic-based companies. This discrepancy is considered natural because GRI is an organization dominated by westerners, resulting in standards that are more in line with conventional companies (Alam et al., 2017).

In addition to knowing how the differences in the environmental disclosure in conventional banking and Islamic banking, this study also looks at the differences in the assessment of the environmental disclosure of the Islamic banking as measured by the GRI index and the ISR index. In this study, the measure used to assess the level of ISR disclosure was the ISR index designed by Othman et al. (2009).

\section{CONCLUSION AND RECOMMENDATION Conclusions}

This study aims to determine what differences are found in environmental disclosure in conventional banking and Islamic banking using the GRI index. This study found that conventional banking has a higher environmental disclosure than Islamic banking. The item of reducing energy consumption is the item most frequently disclosed by conventional banking and Islamic banking. In addition, the results of this study indicate that the environmental disclosure of the Islamic banking is more representative when using the ISR index as compared to the GRI index.

One of the implementations of banking transparency principles is by conducting environmental disclosures. This implementation can increase the reputation and value of the company, which has an impact on increasing the trust of consumers and society. In the policy aspect, this research contributes to supporting the importance of regulation for bank financial institutions to practice more ethically towards environmentally friendly banks.

\section{Recommendation}

It is important for banks to implement and report CSR, especially on environmental disclosure, not only to comply with existing regulations but also more in the awareness that by doing CSR, they will get a competitive advantage which will have an impact on a good reputation and in the end can improve long-term financial performance. For future researchers, it is advisable to conduct further research to determine the motivation of banking companies on environmental disclosure efforts in the annual report and in the sustainability report by using primary data sources such as questionnaires.

\section{REFERENCES}

Ageron, B., Gunasekaran, A., \& Spalanzani, A. (2012). Sustainable supply management: An empirical study. International Journal of Production Economics, 140(1), 168-182. https://doi.org/10.1016/j.ijpe.2011.04.007

Al-Tuwaijri, S. A., Christensen, T. E., \& Hughes, K. E. (2005). The Relations Among Environmental Disclosure, Environmental Performance, and Economic Performance: A Simultaneous Equations Approach. SSRN Electronic Journal, August. https://doi.org/10.2139/ssrn.405643

Alam, M. M., Akbar, C. S., Shahriar, S. M., \& Elahi, M. M. (2017). The Islamic Shariah principles for investment in stock market. Qualitative Research in Financial Markets, 9(2), 132-146. https://doi.org/10.1108/QRFM-09-2016-0029

Ane, P. (2012). An Assessment of the Quality of Environmental Information Disclosure of Corporation in China. Systems Engineering Procedia, 5, 420-426. https://doi.org/10.1016/j.sepro.2012.04.064

Argandoña, A. (1998). The Stakeholder Theory and the Common Good Society and sociability. Journal 
Rizky Windar Amelia, Aditya Pandu Wicaksana, Desi Zulvina, and Sysca Lady Sulistyowatie: How is using of the Indonesian Banking Environmental Disclosure with GRI?

of Business Ethics, 80(4), 879-888.

Baboukardos, D. (2018). The valuation relevance of environmental performance revisited: The moderating role of environmental provisions. British Accounting Review, 50(1), 32-47. https://doi.org/10.1016/j.bar.2017.09.002

Bai, Y., Faure, M., \& Liu, J. (2013). The role of china's banking sector in providing green finance. Duke Environmental Law and Policy Forum, 24(1), 89-140.

Belal, A. R., Abdelsalam, 0., \& Nizamee, S. S. (2015). Ethical Reporting in Islami Bank Bangladesh Limited (1983-2010). Journal of Business Ethics, 129(4), 769-784. https://doi.org/10.1007/s10551- 014 2133-8

Belkaoui, A. (1980). The impact of socio-economic accounting statements on the investment decision: An empirical study. Accounting, Organizations and Society, 5(3), 263-283. https://doi.org/10.1016/0361-3682(80)90001-X

Berthelot, S., \& Robert, A.-M. (2011). Climate Change Disclosures: An Examination of Canadian Oil and Gas Firms. Issues In Social And Environmental Accounting, 5(2), 106. https://doi.org/10.22164/isea.v5i2.61

Branco, M. C., \& Rodrigues, L. L. (2006). Communication of corporate social responsibility by Portuguese banks: A legitimacy theory perspective. Corporate Communications, 11(3), 232-248. https://doi.org/10.1108/13563280610680821

Bryson, D., Atwal, G., \& Dave, K. (2016). Antecedents of Intention to Use Green Banking. 567, 551-567. https://doi.org/10.1002/jsc

Clarkson, P. M., Li, Y., Richardson, G. D., \& Vasvari, F. P. (2008). Revisiting the relation between environmental performance and environmental disclosure: An empirical analysis. Accounting, Organizations and Society, 33(4-5), 303-327. https://doi.org/10.1016/j.aos.2007.05.003

Dong, S., Xu, L., \& McIver, R. (2020). China's financial sector sustainability and "green finance" disclosures. Sustainability Accounting, Management and Policy Journal. https://doi.org/10.1108/SAM PJ-10-2018-0273

Economics, G. (2016). Corporate sustainability reporting in the banking sector of Bangladesh: an appraisal of the G4 of the Global Reporting Initiative Md . Nazrul Islam and Mohammad Ashraful Ferdous Chowdhury *. 10, 252-278.

Elasrag, H. (2015). Corporate Social Responsibility in Islam. SSRN Electronic Journal. https://doi.org/10.2139/ssrn.2593945

Fernando, P. M. P., \& Fernando, K. S. D. (2017). Selected Papers from the Asia-Pacific Conference on Economics \& Finance (APEF 2016). Selected Papers from the Asia-Pacific Conference on Economics \& Finance (APEF 2016), Apef 2016. https://doi.org/10.1007/978-981-10-3566-1

Financial Services Authority Regulation Number: 51 / POJK.03 /2017 About The Implementation of Sustainable Finance for Financial Service Institutions, Issuers, and Public Companies.

Freeman, R. E. E., \& McVea, J. (2005). A Stakeholder Approach to Strategic Management. SSRN Electronic Journal, January. https://doi.org/10.2139/ssrn.263511

Freeman, R. E., Kujala, J., Sachs, S., \& Stutz, C. (2017). Stakeholder Engagement: Practicing the Ideas of Stakeholder Theory. 1-12. https://doi.org/10.1007/978-3-319-62785-4_1

Friedman, A. L., \& Miles, S. (2002). Developing stakeholder theory. Journal of Management Studies, 39(1), 1-21. https://doi.org/10.1111/1467-6486.00280

Gray, R., \& Bebbington, J. (2000). Environmental accounting, managerialism and sustainability: Is the planet safe in the hands of business and accounting? Advances in Environmental Accounting and Management, 1(December), 1-44. https://doi.org/10.1016/S1479-3598(00)01004-9

Government Regulation Number: 47 of 2012 About Social and Environmental Responsibility of Limited Liability Companies.

Gray, R., Kouhy, R., \& Lavers, S. (1995). Corporate Social and Longitudinal Study Of UK Disclosure. Accounting, Auditing \& Accountability Journal, 8(2), 47-77.

Gupta, J. (2015). Role of Green Banking in Environment Sustainability - A study of selected Commercial Banks in Himachal Pradesh. International Journal of Multidisciplinary Research and Development, 2(8), 349-353. https://doi.org/10.13140/RG.2.2.33734.78407

Haniffa, R., \& Hudaib, M. (2007). Exploring the ethical identity of Islamic Banks via communication in annual reports. Journal of Business Ethics, 76(1), 97-116. https://doi.org/10.1007/s10551-0069272-5

Hart, S. L., Milstein, M. B., \& Caggiano, J. (2003). Creating sustainable value. Academy of Management Executive, 17(2), 56-69. https://doi.org/10.5465/ame.2003.10025194 
Hartanti, D. dan Fitria, S. (2010). Islam Dan Tanggung Jawab Sosial: Studi Perbandingan Pengungkapan Berdasarkan Global Reporting Initiative Indeks dan Islamic Social Reporting Indeks.

Hummel, K., Laun, U., \& Krauss, A. (2020). Management of environmental and social risks and topics in the banking sector - An empirical investigation. British Accounting Review, December 2015, 100921. https://doi.org/10.1016/j.bar.2020.100921

Indonesian Government. (2014). Indonesian Government Law No 79 In 2014 About National Energy Policy. 8.

Iqbal, M., Suviitawat, A., Nisha, N., \& Rifat, A. (2016). The role of commercial banks in green banking adoption: a Bangladesh perspective. International Journal of Green Economics, 10(3/4), 226. https://doi.org/10.1504/ijge.2016.10002862

Khalil, S., \& O'sullivan, P. (2017). Corporate social responsibility: Internet social and environmental reporting by banks. Meditari Accountancy Research, 25(3), 414-446. https://doi.org/10.1108/MEDAR-10-2016-0082

Kumar, R., Pande, N., \& Afreen, S. (2018). Developing a GRI-G4-based persuasive communication framework for sustainability reporting (SR): Examining top 10 Indian banks. International Journal of Emerging Markets, 13(1), 136-161. https://doi.org/10.1108/IJoEM-01-2017-0015

Laplume, A. O., Sonpar, K., \& Litz, R. A. (2008). Stakeholder theory: Reviewing a theory that moves us. In Journal of Management (Vol. 34, Issue 6). https://doi.org/10.1177/0149206308324322

Law of the Republic of Indonesia Number: 40 of 2007 About Limited Liability Companies.

Law of the Republic of Indonesia Number: 32 of 2009 About Environmental Protection and Management.

Leipziger, D. (2015). The Global Reporting Initiative. The Corporate Responsibility Code Book: Third Edition, 516-538. https://doi.org/10.9774/gleaf.9781783530670_31

Mara, U. T., \& Mara, U. T. (2014). Social responsibility reporting of Islamic banks : evidence from Indonesia Faizah Darus * Hasan Fauzi Yadi Purwanto Haslinda Yusoff Azlan Amran Mustaffa Mohamed Zain and Dayang Milianna Abang Naim Mehran Nejati.9(4), 356-380.

Martins, F. S., Cunha, J. A. C. da, \& Serra, F. A. R. (2018). Secondary Data in Research - Uses and Opportunities. Revista Ibero-Americana de Estratégia, 17(04), 01-04. https://doi.org/10.5585/i jsm.v17i4.2723

Meng, X., Shi, L., Yao, L., Zhang, Y., \& Cui, L. (2020). ur na I P re of. Colloids and Surfaces A:Physicochemical and Engineering Aspects, Iii, 124658. https://doi.org/10.1016/j.jclepro.2020.124840

Miah, M. D., Rahman, S. M., \& Mamoon, M. (2020). Green banking: the case of commercial banking sector in Oman. Environment, Development and Sustainability, 0123456789. https://doi.org/10.1007/s10668-020-00695-0

Mohamed Zain, M., Darus, F., Yusoff, H., Amran, A., Fauzi, H., Purwanto, Y., \& Abang Naim, D. M. (2014). Corporate ibadah: an Islamic perspective of corporate social responsibility. Middle-East Journal, 22(2), 225-232. https://doi.org/10.5829/idosi.mejsr.2014.22.02.21850

Nizam, E., Ng, A., Dewandaru, G., Nagayev, R., \& Nkoba, M. A. (2019). The impact of social and environmental sustainability on financial performance: A global analysis of the banking sector. Journal of Multinational Financial Management, 49, 35-53. https://doi.org/10.1016/j.mulfin.2019.01.002

Nobanee, H., \& Ellili, N. (2016). Corporate sustainability disclosure in annual reports: Evidence from UAE banks: Islamic versus conventional. Renewable and Sustainable Energy Reviews, 55, 13361341. https://doi.org/10.1016/j.rs er.2015.07.084

Nugraheni, P., \& Azlan Anuar, H. (2014). Implications of Shariah on the voluntary disclosure of Indonesian listed companies . Journal of Financial Reporting and Accounting, 12(1), 76-98. https://doi.org/10.1108/jfra-11-2011-0018

Othman, R., Thani, A. M., \& Ghani, E. K. (2009). Determinants Of Islamic Social Reporting Among Top Shariah -Approved Companies In Bursa Malaysia. Research Journal of International Studies, 12(12), 4-20.

Otoritas Jasa Keuangan. (2015). Roadmap Keuangan Berkelanjutan di Indonesia Roadmap for Sustainable Finance in Indonesia 2015-2019. Otoritas Jasa Keuangan, 1-40.

Parmar, B. L., Freeman, R. E., Harrison, J. S., Wicks, A. C., Purnell, L., \& de Colle, S. (2010). Stakehol der theory: The state of the art. Academy of Management Annals, 4(1), 403-445. https://doi.org/10.1080/19416520.2010.495581

Plumlee, M., Brown, D., Hayes, R. M., \& Marshall, R. S. (2015). Voluntary environmental disclosure quality and firm value: Further evidence. Journal of Accounting and Public Policy, 34(4), 336-361. https://doi.org/10.1016/j.jaccpubpol.2015.04.004 
Sahoo, P., \& Nayak, B. P. (2007). Green Banking in India. The Indian Economic Journal, 55(3), 82-98. https://doi.org/10.1177/0019466220070306

Santoso, N. T., Ningsih, R. M., \& Paramitha, R. P. (2018). Determinants of Islamic Social Reporting Disclosure: The Case of Jakarta Islamic Index. State-of-the-Art Theories and Empirical Evidence, 2739. https://doi.org/10.1007/978-981-10-6926-0_2

Saridona, R., \& Cahyandito, M. F. (2015). Social Performance Analysis of Indonesia Islamic Banking Using Islamic Social Reporting Index. 2010, 194-200. https://doi.org/10.2991/iceb-15.2015.29

Shaumya, K., \& Arulrajah, A. A. (2017). Measuring Green Banking Practices: Evidence from Sri Lanka. SSRN Electronic Journal, 999-1023. https://doi.org/10.2139/ssrn. 2909735

Sobhani, F. A., Amran, A., \& Zainuddin, Y. (2012). Sustainability disclosure in annual reports and websites: A study of the banking industry in Bangladesh. Journal of Cleaner Production, 23(1), 7585. https://doi.org/10.1016/j.jclepro.2011.09.023

Sunarsih, U., \& Ferdiansyah, F. (2016). Determinants of The Islamic Social Reporting Disclosure. AlIqtishad: Journal of Islamic Economics, 9(1), 69-80. https://doi.org/10.15408/aiq.v9i1.3771

Tafti, S. F., Hosseini, S. F., \& Emami, S. A. (2012). Assessment the Corporate Social Responsibility According to Islamic Values (Case Study: Sarmayeh Bank). Procedia - Social and Behavioral Sciences, 58, 1139-1148. https://doi.org/10.1016/j.sbspro.2012.09.1095

Traxler, A. A., Greiling, D., \& Hebesberger, H. (2018). GRI Sustainability Reporting by INGOs: A Way Forward for Improving Accountability? Voluntas, 1-17. https://doi.org/10.1007/s11266-0189976-Z

Tsalis, T. A., Nikolaou, I. E., Konstantakopoulou, F., Zhang, Y., \& Evangelinos, K. I. (2020). Evaluating the corporate environmental profile by analyzing corporate social responsibility reports. Economic Analysis and Policy, 66, 63-75. https://doi.org/10.1016/j.eap.2020.02.009

Ullmann, A. A. (1985). Data in Search of a Theory: A Critical Examination of the Relationships among Social Performance, Social Disclosure, and Economic Performance of U. S. Firms. The Academy of Management Review, 10(3), 540. https://doi.org/10.2307/258135

Vernon, P. (2015). Sustainable development goals. Economist (United Kingdom), 411(8953).

Wang, S., Wang, H., Wang, J., \& Yang, F. (2020). Does environmental information disclosure contribute to improve firm financial performance? An examination of the underlying mechanism. Science of the Total Environment, 714(96), 136855. https://doi.org/10.1016/j.scitotenv.2020.136855

Wheeler, D., Colbert, B., \& Freeman, R. E. (2003). Focusing on Value: Reconciling Corporate Social Responsibility, Sustainability and a Stakeholder Approach in a Network World. Journal of General Management, 28(3), 1-28. https://doi.org/10.1177/030630700302800301

Zafar, M. B., \& Sulaiman, A. A. (2019). Corporate social responsibility and Islamic banks: a systematic literature review. Management Review Quarterly, 69(2), 159-206. https://doi.org/10.1007/s11301-018-0150-x

Zhang, Y., Ren, S., Liu, Y., \& Si, S. (2017). A big data analytics architecture for cleaner manufacturing and maintenance processes of complex products. Journal of Cleaner Production, 142, 626-641. https://doi.org/10.1016/j.jclepro.2016.07.123

Ziolo, M., Pawlaczyk, M., \& Sawicki, P. (2019). Sustainable Development Versus Green Banking: Where Is the Link?53-81. https://doi.org/10.1007/978-3-030-16522-2_3

www.bi.go.id

www.globalreporting.org

www.worldbank.org 